\title{
Abuse in South African maternity settings is a disgrace: Potential solutions to the problem
}

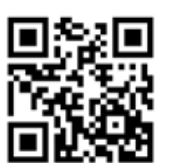

Abuse of patients by healthcare staff in maternity settings has been reported globally, in high- and lowincome settings. ${ }^{[1]}$ Such behaviours include verbal abuse, physical abuse, non-consensual care, non-confidential care, neglect, abandonment of care and bribery. Review articles suggest that the causes are multifactorial, including lack of professional support for healthcare workers, hierarchical work relationships, excessive workload, inadequate staffing levels and poor infrastructure.$^{[1]}$ A World Health Organization statement in 2014 emphasised that the problem of disrespect and abuse of women during facility-based childbirth is a global phenomenon requiring urgent attention. ${ }^{[2]}$

In South Africa (SA) the problem has been documented and studied over many decades ${ }^{[3-5]}$ and was described by Prof. Lynette Denny, Head of the Department of Obstetrics and Gynaecology at the University of Cape Town, as 'one of the world's great disgraces' (personal communication). Studies in maternity facilities have documented staff rudeness, arbitrary acts of unkindness, clinical neglect, verbal abuse, psychological abuse, physical assault and sexual violence. ${ }^{[6-8]}$ Studies in community-based maternity care facilities found that many women express expectations of being 'shouted at, beaten or neglected?.[6]

\section{The context of maternity services in SA}

Healthcare workers' working environments are influenced by physical, social and psychological factors that result in a range of occupational stressors ${ }^{[9,10]}$ and affect the staff-patient relationship and the quality of care provided. SA public sector facilities serve $85 \%$ of the population. ${ }^{[11]}$ An unequal healthcare system, inherited from the apartheid era, ${ }^{[12]}$ is characterised by maldistribution of health workers and resources, ${ }^{[11,13]}$ poorly funded facilities and a lack of mentorship and leadership, ${ }^{[14,15]}$ demoralisation and a lack of motivation, ${ }^{[6,12,16,17]}$ high responsibility, excessive overtime demands, task overload and an ever-burgeoning demand for health services. ${ }^{[15]}$ Abusive behaviour in this context may result from staff's perceived sense of powerlessness to intervene.

Studies documenting the prevalence of diagnosed antenatal and postnatal depression in SA have shown rates of $47 \%{ }^{[18]}$ and $34 \%,{ }^{[19]}$ respectively. Despite this, primary healthcare providers are not trained to detect mental illness, ${ }^{[20]}$ and their working environment does not provide the resources or support structures that they need in order to offer the appropriate care. ${ }^{[21]}$ The additional emotional burden imposed by mental illness in this setting can compound exhaustion, burnout and compassion fatigue among staff. ${ }^{[1]}$ This may contribute to the development of common mental disorders among staff themselves, which in turn may further exacerbate their disengagement from or abuse of their patients. ${ }^{[2]}$

The dysfunctional relationship between healthcare worker and patient can be exaggerated by the vulnerability of being in labour ${ }^{[7,23]}$ and the fact that for a range of reasons many women in the SA setting have no birthing companion. ${ }^{[6,24-26]}$

\section{Solutions: Global and national initiatives to address abuse of women in labour}

The rights-based approach provides an important framework to address the problem of abuse of maternity patients and seeks to ensure accountability of health professionals and managers for poor quality of care. ${ }^{[27]}$ There are two critical components of quality of care: firstly, evidence-based effective care to reduce adverse maternal and perinatal outcomes, and secondly, patientcentred care in which women are treated with respect and dignity. Care for health workers themselves is a vital element of the latter. ${ }^{[28]}$

There are examples of initiatives at global and country level to address abuse of women in labour and promote effective care. These include the Humanising Childbirth Movement (predominantly South America), ${ }^{[29]}$ the Better Births Initiative (SA), ${ }^{[30]}$ and more recently the Respectful Maternity Care Movement (Mozambique, Ethiopia) ${ }^{[31-34]}$ and the Heshima Project (Kenya). ${ }^{[34]}$

\section{The Patient-Centred Maternity Care Code in the Cape Metro}

This was introduced in 2013 in response to complaints from women about their care and widespread observations by 4 th-year medical students of disrespectful behaviour by maternity health staff. A meeting was convened by the head of the Cape Town Metro District Health Services and senior academics from the departments of Public Health and Obstetrics and Gynaecology of the University of Cape Town, and a task team was established. A code for patient-centred maternity care was developed that includes zero tolerance for abusive or disrespectful behaviour, but also addresses health system problems which may contribute to such behaviours.

The objectives of the code are as follows:

- Every woman or every couple seeking maternity care has the right to effective healthcare and the right to be treated with respect and dignity.

- Every woman or every couple has the right to information about pregnancy and the necessary obstetric care.

- Every woman to have a chosen personal and/or facility-provided companion while in labour.

- Maternity facilities to be responsive to the communities they serve.

Each objective includes a list of specific actions, for example friendly reception, a respectful approach by the health worker to the woman in labour, and supply chain/infrastructure improvements. Monitoring and implementation tools have been developed. Educational and information pamphlets about maternity care, companions and the code have been produced.

The code, which has been formally adopted as Western Cape Health policy, coheres with Western Cape Health's strategy of 'patientcentred care', the core values of which are Caring, Competence, Accountability, Integrity, Responsiveness and Respect $\left(\mathrm{C}^{2} \mathrm{AIR}^{2}\right)$. 
The process has been slow to implement, with many challenges identified by an initial participatory action research evaluation (J Rucell, School of Politics and International Studies, University of Leeds, UK - personal communication to the Metro task team, December 2013). It was difficult to get 'buy-in' from all staff, and there was fear of disciplinary action or suspension. There were challenges in providing proper debriefing mechanisms and adequate training, and in addressing infrastructural and procurement problems.

The programme has now been decentralised to the substructure level, where there will be a multidisciplinary approach to promoting patient-centred maternity care with inputs from medical and nursing schools, managers and healthcare staff in maternity facilities.

\section{Birth companions as a method for improving women's experience of care in labour}

One maternity care practice for which there is considerable evidence of benefit is that of providing companions and emotional support for women in labour. This can be in the form of a personal companion (partner, mother, aunt, etc.), or a lay supporter or 'doula' (a woman who cares for other women). A Cochrane review in 2011 of 22 randomised controlled trials involving 15000 women and investigating 'continuous support for women during childbirth' showed the following significant benefits: women were more likely to have spontaneous birth, less likely to require intrapartum analgesia, and less likely to report dissatisfaction; their labours were slightly shorter; they were less likely to require caesarean section, instrumental delivery or regional analgesia; and they were less likely to have a baby with a low 5-minute Apgar score. ${ }^{[35]}$ Despite there being more evidence for this practice than for many other interventions in labour, its implementation in public sector maternity wards is often impeded by infrastructural problems such as poor security, lack of privacy and a lack of enabling policies.

\section{Healthcare worker training and emotional support: The Secret History method}

The Perinatal Mental Health Project ${ }^{[36]}$ at the University of Cape Town developed the Secret History training method in 2004. The project has used this approach in a wide variety of settings with a range of healthcare workers, and the training has undergone qualitative internal and external evaluation. The aim is to improve empathic engagement skills of healthcare staff working with mothers.

The group role-play facilitates an enactment of typical dysfunctional responses between healthcare worker and patient through a case story unfolding between them, over the course of pregnancy and labour, and postnatally. The secret history of each character is revealed in stages. Participants have a chance to 'play' one of the two roles and are then asked to switch roles half way through the story. At each phase of the story, the players are asked to identify their feelings and needs, both as the healthcare worker and as the mother.

Identifying with 'the other' is a critical element of the training and allows for dissolution or reframing of unhelpful cognitions. A process of reintegration of self and 'other' follows. This allows participants to engage with a wider context of maternal care, one which encourages empathy for the 'other' and validates sympathy for the 'self'. Participants are then able to develop their own solutions to address difficulties in the workplace and interpersonal challenges with colleagues and patients, and to be more supportive of the needs of patients and each other.

\section{Conclusions}

Disrespect and abuse of women during childbirth is an infringement of women's human rights and a deterrent to seeking care, thus resulting in adverse pregnancy outcomes. It is therefore each healthcare worker's professional and ethical obligation to report observed abuses to senior management.

The promotion of respectful maternity care requires attitudinal changes by staff, staff support mechanisms, adequate training, appropriate infrastructure, functioning procurement processes, and effective clinical and managerial governance.

\section{Simone Honikman}

Perinatal Mental Health Project, Alan J Flisher Centre for Public

Mental Health, University of Cape Town, South Africa, and Professional Standards Committee, University of Cape Town

\section{Sue Fawcus}

Department of Obstetrics and Gynaecology, University of Cape Town, South Africa, and Head of Obstetric Services, Mowbray Maternity Hospital, Cape Town

Ingrid Meintjes

Perinatal Mental Health Project, Alan J Flisher Centre for Public Mental Health, University of Cape Town, South Africa

\section{Corresponding author: S Honikman (simone.honikman@uct.ac.za)}

Bowser D, Hill K. Exploring Evidence for Disrespect and Abuse in Facility-based Childbirth. USAID, 2010. http://wordpress.sph.harvard.edu/mhtf-2/wp-content/uploads/sites/32/2014/08/RespectfulCareatBirth920-101Final.pdf (accessed 27 February 2015)

World Health Organization Human Reproduction Programme Statement. The Prevention and Elimination of Disrespect and Abuse during Facility Based Childbirth. Geneva: WHO, 2014.

3. Abrahams N, Jewkes R, Mvo Z. Health care-seeking practices of pregnant women and the role of the midwife in Cape Town, South Africa. J Midwifery Womens Health 2001;46(4):240-247. [http://dx.doi. org/10.1016/S1526-9523(01)00138-6

4. Farrell E, Pattinson RC. Out of the mouths of babes - innocent reporting of harmful labour ward practices. S Afr Med J 2004;94(11):896-897.

5. Human Rights Watch. 'Stop Making Excuses': Accountability for Maternal Health Care in South Africa. http://www.hrw.org/reports/2011/08/08/stop-making-excuses-0 (accessed 10 March 2014).

6. Jewkes R, Abrahams N, Mvo Z. Why do nurses abuse patients? Reflections from South African obstetric Jewkes R, Abrahams N, Mvo Z. Why do nurses abuse patients? Reflections from South African obstetic
services. Soc Sci Med 1998;47(11):1781-1795. [http://dx.doi.org/10.1016/S0277-9536(98)00240-8]

Kruger L, Schoombee C. The other side of caring: Abuse in a South African maternity ward. J Reprod Kruger L, Schoombee C. The other side of caring: Abuse in a South African mater
Infant Psychol 2010;28(1):84-101. [http://dx.doi.org/10.1080/02646830903294979] Infant Psychol 2010;28(1):84-101. [http://dx.doi.org/10.1080/02646830903294979]
8. Khalil D. Public hospitals. Nurs Forum 2009;44(3):207-217. [http://dx.doi.org/10.1111/.1744-6198.2009.00144]

8. Khali D. Public hospitals. Nurs Forum 2009;44(3):207-217. [http://dx.doi.org/10.1111/.1744-6198.2009.00144]
9. Chan AOM, Huak CY. Influence of work environment on emotional health in a health care setting Occup Med 2004;54(3):207-212. [http://dx.doi.org/10.1093/occmed/kqh062]

10. Klopper HC, Coetzee SK, Pretorius R, Bester P. Practice environment, job satisfaction and burnout of critical care nurses in South Africa. J Nurs Manag 2012;20(5):685-695. [http://dx.doi.org/10.1111/.j.1365-2834.2011.01350.x]

11. Breier M, Wildschut A, Mgqolozana T. Nursing in a New Era: The Profession and Education of Nurses in South Africa. Cape Town: Human Sciences Research Council, 2009.

12. Coovadia H, Jewkes R, Barron P, Sanders D, McIntyre D. The health and health system of South Africa: Historical roots of current public health challenges. Lancet 2009;374(9692):817-834. [http://dx.doi. org/10.1016/S0140-6736(09)60951-X]

13. Zachariah R, Ford N, Philips M, et al. Task shifting in HIV/AIDS: Opportunities, challenges and proposed actions for sub-Saharan Africa. Trans R Soc Trop Med Hyg 2009;103(6):549-558. [http:// dx.doi.org/10.1016/.trstmh.2008.09.019]

14. Saxena S, Thornicroft G, Knapp M, Whiteford $H$. Resources for mental health: Scarcity, inequity, and inefficiency. Lancet 2007;370(9590):878-889. [http://dx.doi.org/10.1016/S0140-6736(07)61239-2]

15. Pillay R. Retention strategies for professional nurses in South Africa. Leadersh Health Serv 2009;22(1):39-57. [http://dx.doi.org/10.1108/17511870910928010]

16. Kim J, Motsei M. 'Women enjoy punishment': Attitudes and experiences of gender-based violence among PHC nurses in rural South Africa. Soc Sci Med 2002;54(8):1243-1254. [http://dx.doi.org/10.1016/S0277-9536(01)00093-4]

17. Chopra M, Lawn JE, Sanders D, et al. Achieving the health Millennium Development Goals for South Africa: Challenges and priorities. Lancet 2009;374(9694):1023-1031. [http://dx.doi.org/10.1016/S0140-6736(09)61122-3]

18. Rochat T,, Tomlinson M, Bärnighausen T, Newell M-L, Stein A. The prevalence and clinical presentation of antenatal depression in rural South Africa. J Affect Disord 2011;135(1):362-373. [http://dx.doi.org/10.1016/j.jad.2011.08.011]

9. Cooper PI, Tomlinson M, Swartz L, Woolgar M, Murray L, Molteno C. Post-partum depression and the mother-infant relationship in a South African peri-urban settlement. Br J Psychiatry 1999;175(6):554558. [http://dx.doi.org/10.1111/j.1365-2214.2006.00598 x]

20. Hamad R, Fernald LCH, Karlan DS, Zinman J. Social and economic correlates of depressive symptoms and perceived stress in South African adults. J Epidemiol Community Health 2008;62(6):538-544. http://dx.doi.org/10.1136/jech.2007.066191]

21. Moyle W. Nurse-patient relationship: A dichotomy of expectations. Int I Ment Health Nurs 2003;12(2):103-109. [http://dx.doi.org/10.1046/j.1440-0979.2003.00276.x]

22. Van der Colff J, Rothmann S. Occupational stress, sense of coherence, coping, burnout and work engagement of registered nurses in South Africa. South African Journal of Industrial Psychology 2009;35(1):1-10. [http://dx.doi.org/10.4102/sajip.v35i1.423

23. Hodges S. Abuse in hospital-based birth settings? J Perinat Educ 2009;18(4):8-11. [http://dx.doi. org/10.1624/105812409X474663]

24. Gilson L, Daire J. Leadership and governance within the South African health system. In: Padarath A, English R, eds. South African Heath Review. Durban: Health Systems Trust, 2011:66-80.

25. Tomlinson M, Cooper P, Stein A, Swartz L, Molteno C. Post-partum depression and infant growth in a South African peri-urban settlement. Child Care Health Dev 2006;32(1):81-86. [http://dx.doi. org/10.1111/j.1365-2214.2006.00598 x]

26. Kaibe NV. The knowledge of the registration of the role of the doula in the facilitation of natural child birth. Master's thesis (Nursing Science). Tygerberg, Cape Town: Department of Interdisciplinary birth. Master's thesis (Nursing Science). Tyger

27. United Nations General Assembly Human Rights Council. Technical guidance on the application of a human-rights based approach to the implementation of policies and programmes to reduce preventable human-rights based approach to the implementation of policies and programmes to reduce preventable
maternal morbidity and mortality. July 2012. http://www.who.int/pmnch/media/news/2012/20120910 maternal morbidity and mortality. July 2012. http://
humanrightscouncil/en/ (accessed 9 March 2015). 
28. Brodie P. 'Midwifing the midwives': Addressing the empowerment, safety of, and respect for, the world's midwives. Midwifery 2013;29(10):1075-1076. [http://dx.doi.org/10.1016/j.midw.2013.06.012]

29. Goer H. Humanizing birth: A global grassroots movement. Birth 2004;31(4):308-314. [http://dx.doi. org/10.1111/j.0730-7659.2004.00324.x]

30. Smith H, Brown H, Hofmeyr GJ, Garner P. Evidence-based obstetric care in South Africa - influencing practice through the 'Better Births Initiative' S Afr Med J 2004;94(2):117-120.

31. Reis V, Deller B, Carr C, Smith J. Respectful Maternity Care. 2012. https://www.k4health.org/sites/ default/files/RMC Survey Report.pdf (accessed 27 February 2015)

32. Snow J. MCHIP Year Four Annual Report. Baltimore, MD: Johns Hopkins University Press, 2013.

33. K4Health. Respectful maternity care toolkit. http://www.k4health.org/toolkits/rmc (accessed 27 February 2015).
34. Warren C, Njuki R, Abuya T, et al. Study protocol for promoting respectful maternity care initiative to assess, measure and design interventions to reduce disrespect and abuse during childbirth in Kenya. BMC Pregnancy Childbirth 2013;13(1):21-29. [http://dx.doi.org/10.1186/1471-2393-13-21]

35. Hodnett ED, Gates S, Hofmeyr GJ, Sakala C, Weston I. Continuous support for women during childbirth. Cochrane Database Syst Rev 2013, Issue 7. Art. No.: CD003766. [http://dx.doi.org/10.1002/14651858.CD003766.pub5]

36. Field S, Baron E, Meinties I, van Heyningen T, Honikman S. Maternal mental health care: refining the . Field S, Baron E, Meintjes I, van Heyningen T, Honikman S. Maternal mental health care: refining the
components in a South African setting. In: Okpaku SO, ed. Essentials of Global Mental Health. Cambridge: Cambridge University Press, 2014:173-186.

S Afr Med J 2015;105(4):284-286. DOI:10.7196/SAMJ.9582 